\title{
Bridging the Gap between Curriculum Planning Policies and Pre-service Teachers' Needs
}

\author{
Angela Yicely Castro-Garces ${ }^{1} \&$ Argemiro Arboleda Arboleda ${ }^{2}$ \\ ${ }^{1}$ English and Spanish Department, Universidad del Tolima, Ibagué, Colombia \\ ${ }^{2}$ Foreing Languages Department, Universidad del Valle, Cali, Colombia \\ Correspondence: Angela Yicely Castro-Garces, English and Spanish Department, Universidad del Tolima, \\ Ibague, Colombia. Barrio Santa Helena Parte Alta. E-mail: aycastrog@ut.edu.co; \\ argemiro.arboleda@correounivalle.edu.co
}

Received: October 9, 2017 Accepted: October 30, 2017 Online Published: November 3, 2017

doi: 10.5539/elt.v10n12p50 URL: http://doi.org/10.5539/elt.v10n12p50

\begin{abstract}
The challenge and satisfaction of being a teacher is doubled when one has the precious task of being a teacher trainer, as our practices replicate exponentially, touching the lives of people we do not even get to meet. Accordingly, this article presents the analysis of a process that brought tensions to a teacher training program because of the need to comply with the guidelines of the National Ministry of Education while considering pre-service teachers' needs. Thus, a descriptive analysis was done, through a questionnaire, with the objective of portraying pre-service teachers' perceptions about the curriculum that underlies their teaching training program, and characterizing their contributions in the face of a new curriculum design. The gains obtained out of the participants' insights were key in understading their feelings and provided a good source of information for the new curriculum. The results suggest that pre-service teachers' perceptions broaden teacher trainers' horizons and enrich curriculum planning as a step towards meaningful and inclusive learning.
\end{abstract}

Keywords: planning policies, curriculum, pre-service teachers, quality of education

\section{Introduction}

The discussion about the gestation and implementation of educational policies is relevant at all educational levels, even more so in contexts where some of the actors involved in education have no say in the establishment of norms and principles that will govern it, nor in the design of the instruments, methods and means to successfully carry out the important task of educating. On the one hand, and even if it may sound paradoxical, the teacher, who in our contemporary education has been consecrated as a means between knowledge and student, is the last one to know about the changes that will occur in his classroom. On the other hand, the student, very often, a prisoner of what Freire (1972) considers 'banking education', is taken as a passive subject, 'the container in which knowledge is to be deposited', unable to decide for himself and to contribute to the construction of that high educational level which we are eager to reach.

Thus, the aim of this article is to analyze the perceptions of pre-service English teachers about the curriculum that underlies their program and to characterize their contributions against a new curriculum design. Although these curriculum changes were motivated by a resolution issued by the National Ministry of Education, which regulates quality features for teacher training programs, the said resolution has also been seen as the opportunity to make significant transformations that favor our local and regional environment, in line with the globality that frames us. Thus, Canagarajah (2005) sugests the need to locate and decolonize learning and to propose transformative solutions. He considers local knowledge as situated and socially negotiated knowledge. After asking ourselves, teacher trainers, multiple questions, such as: Are we ready for the change? Do we have the possibility to decide how to implement it? Is it possible to achieve the quality required of us with the existing conditions and resources? We took the challenge of rethinking the curriculum, reflecting on the strengths and considering working on the weaknesses.

Although by adhering to broad guidelines, the curriculum committee of an academic program has the opportunity to make some important decisions that will directly influence pre-service teachers' education, it is considered that their voices must be heard because they are the ones who have experienced the learning of each 
subject. Therefore, we decided to administer a questionnaire to eighth-semester pre-service teachers to know their perceptions and contributions to the program. Similarly, because they are pre-service teachers already involved with educational institutions while completing their teaching practicum, they have the criteria to know how much the education they have received at university is related to their social reality.

This article presents a description of the panorama found through inquiry and a reflection on the need to involve pre-service teachers in the design of more inclusive, critical and social curricula.

\section{Theoretical Framework}

This analysis is based on reforms, very often forged exogenously by different institutions, and in others by collegiate groups, including University Academic Boards, Municipal and Departmental Educational Boards, the National Ministry of Education and International Organizations. This section briefly depicts contributions of different groups to the construction of educational policies, as well as the following theoretical constructs that enrich the discussion on the matter under study: teacher training programs and pre-service teachers, flexible, inclusive, critical and social curriculum, and quality of education.

\subsection{Educational Policies and Organizations Involved}

Different international organizations such as the World Bank, UNESCO, PREAL, after conducting studies on how educational policies in Latin America are advancing, recommend strategies for improving the quality of education. For example, PREAL generally praises the efforts of governments to undertake national or sectoral consultations and to create advisory councils, with delegates from universities and other educational institutions to define policy implementation strategies (Krawczyk, 2002).

On the other hand, UNESCO creates warnings on the problems in the educational system and points out the great gap between public and private education, highlighting historical economic inequalities (UNESCO, 2011). Likewise, six international objectives are proposed, which guarantee education for all; the sixth one being within the scope of this article because its objective is to improve the quality of education. Emphasis is placed on a comprehensive vision of learning and education as a human right (ibid). However, it also reflects the delegation of guilt and implicit nonage of our Latin American countries, which, apparently, cannot stand on their own and therefore need to be saved by those who claim to have solutions.

Rivero (2000), for instance, contends that successive and different proposals for reform have often sought to subordinate educational processes to economic needs. Other proposed changes include the desire to obtain quality education with lower costs. The failures experienced in multiple attempts to legislate utopian and out-of-context changes have created skepticism with logical arguments, suggesting the formulation of contextualized and reality-based reforms. Rivero (2000) also states that international financing agencies, particularly the World Bank, have been and are decisive for the cost-benefit ratio and rate of return to influence the definition of investment priorities by educational levels and for quality criteria to be associated with skills and performance.

It is clear how education becomes a business that is expected to make an economic profit. Speaking of cost-benefit seeks to ensure that institutions are self-sustaining, but the impact of a society with better educated children and young people is not measured in the medium and long term. If we give those who will be the future of our society the opportunity to access quality education, with the resources necessary to achieve it, to be proactive and propositive in a student-centered learning, the gains will exceed the economic factor because these same children will create a more tolerant and inclusive society, one capable of shaping more dignifying living conditions. In Freire's (1989) words, there is the need to build a critical citizenship, formed through interpersonal relationships and negotiation, so that the school functions as a democratic organization where the members actively participate discussing and thinking critically. Without communication there is no real education. Then, the principle of education should be based on the dialogue of people with different perceptions, taking into account the knowledge of all actors involved.

\subsection{Teacher Training Programs and Pre-service Teachers}

In the Colombian context, policies for teacher training programs have recently been modified in accordance with the provisions of Resolution No. 2041 of February 3/2016, which aims to establish quality characteristics for undergraduate academic programs of Bachelor's degree, to renew or modify their official registration (National Ministry of Education, 2016). The guidelines established in this resolution include the denomination of the program, the curriculum contents and the competencies of the educator, among others. Although this regulation requires the fulfillment of certain parameters that guarantee quality, there is also a space to close the gap between curriculum planning and pre-service teachers' needs, as established in Law 30 of 1992, which provides 
university autonomy, by recognizing "the right of universities to change their statutes, designate their academic and administrative authorities, create, organize and develop their academic programs, define and organize their educational, academic, teaching, scientific and cultural work..." (National Ministry of Education, 1992). Although there is no total autonomy for academic programs because the proposed guidelines are somewhat rigid, the little free space for curriculum planning that is provided must be fully used by generating spaces for open dialogue that discuss the essential changes needed to achieve the training of critical, reflective and propositive teachers that can face current challenges in education.

Educational reforms can be seen as an opportunity for improvement. Zaccagnini (2004) considers that an educational reform takes place when the need to implement a change in the structural organization of the system is seen; when the curriculum design is changed; when the system as a whole is intended to be modernized. That is to say, that a reform involves changes in both procedures and paradigms, it implies deep transformation, which requires time and commitment to understand it. Then, for reforms to be successful, it is necessary that all the actors are truly involved, that they believe in them and appropriate them. In othwer words, it is necessary that all these be active participants from the very moment of the reform gestation. Although the picture that is frequently presented to us is not that of reforming based on the needs of the context, the way forward is to make the best out of them, trying to "localize, personalize and humanize" (Tomlinson, 2003).

It is essential to adopt a proactive and reflective position that allows us to take every potential change as an opportunity, as a challenge to be better. Dewey (1933) argues that the capacity for reflection only begins after the recognition of a problem and the acceptance of uncertainty, which makes the reflective thinker an active inquisitor, involved in criticism and the generation of new hypotheses. According to Dewey's ideas, presented almost a century ago, but still relevant today, reflective thinking requires continuous evaluation of our beliefs against existing data and interpretations. This approach has led us to think of an educational future not as a finished matter, but as an education adjusted to time and context.

\subsection{Flexible, Inclusive, Critical and Social Curriculum}

Different teachers' beliefs about the concept of curriculum and the role it plays in teacher education are fundamental and controversial in the university field. Curriculum committees are constituted by teachers with academic training coming from different schools of thought. For some, the curriculum must be student-centered, for others, based on competencies; and still some others consider it the opportunity to make learning more flexible. Rojas-Oviedo (2013) affirms that there will be those who defend the national and only-one curriculum for a whole country, or decentralized in provinces and departments, or designed in the school institutions themselves. In this respect, it is worth reflecting on the institutional aims, for it is essential to have a navigation chart that guides the design of a curriculum structure in accordance with the educational principles that underlie a particular institution. So as not to fall into blindly obeying generalized guidelines as presented by the following definition of public policies: "Government actions in relation to educational practices that pass through the social totality... the way in which the Government resolves production, distribution and appropriation of knowledge" (Imen, 2008). Our proactive attitude becomes urgent because if we cannot rethink our practices in the university and in the classroom, we are subject to replicating others'.

The diverse definitions of curriculum presented by Diaz-Barriga (1989), as cited in Taborda and Buritica (2007), suggest curriculum adaptation to different contexts. Seven different conceptualizations of curriculum are highlighted, ranging from associating it with a technical field to seeing it as an illuminating theoretical field; from those that assume a critical dimension, confronting real curriculum and hidden curriculum to those that formulate the curriculum as a research field. What the author points out is an important referent so as to affirm that there is no universal notion of curriculum -that the term is polysemic.

Likewise, there are other authors who separate curriculum from pedagogy and didactics, while others in turn seek their complementarity. In this way the following question arises: If it is so difficult to come to a unified definition of curriculum, what would be the benefits and drawbacks of designing generalized, authoritarian and decontextualized curricula? Reflection on this invites us to think of delimiting, localizing and contextualizing education more and more, taking into account its beneficiaries. Diaz-Barriga (2003), as cited in Rojas-Oviedo (2013), states that the concept of curriculum is in the process of dissolution as a result of the polysemy that accompanies it. Thus, rather than thinking of a definition that guides our curriculum design, we must reach a consensus on the type of education we want for our pre-service teachers, adjusted to the reality that surrounds them and recognizing the plurality of the individuals.

On the other hand, the idea that not everything that is taught is explicit and regulated is reflected in the concept of hidden curriculum, which was defined by Haralambos (1991) as those things that students learn through the 
experience of coming to school beyond educational goals. Likewise, Meighan and Siraj-Blatchford (1997) argue that hidden curriculum is taught in school, not by a teacher... it is something that appears among students. These views present other perspectives in the educational environment; give the possibility of empowering the student in the development of his own learning process, being a propositive subject able to generate change and build new knowledge.

Tyler (1949) presents three key sources for any curriculum designer: students, society, and content requirements to achieve tentative general goals. These components would form the basis of learning, taking into account the educational principles of society. If at best, the teacher is also an active agent in curriculum design, the latter would be strengthened and a very feasible way to build a good path for learning. Thus, the following reflection on the basis of pre-service teachers' perceptions about the relevance of the aspects that underlie the curriculum design of a program is a sign of the need to involve them as direct beneficiaries. Torres (1998) claims that practical work when there is no reflection is usually and mostly directed by custom, tradition and routine. Due to the many tasks in which we immerse ourselves along our teaching practice, little time is devoted to the indispensable task of reflecting and sharing experiences with colleagues; we pitifully expect, on many occasions, to be warned this need from the outside.

Back to the social reason for education, Torres suggests that educational institutions should always have a close relationship with other spheres of society. Educational policies cannot be understood in isolation, decontextualized from the concrete socio-historical framework in which it takes on real meaning.

\subsection{Quality of Education}

There are diverse conceptions around quality of education, the most common requiring the search for continuous improvement, which would be necessarily linked to the task of the reflective teacher. Thus, it would not be necessary to create norms that seek quality, which are in some way contradictory to the nature of teaching. The search for better teaching practices cannot be imposed, for being a good teacher is born of the soul, from the love of the profession and the students; it is vocation rather than a technique. Kumaravadivelu (2001) proposes pedagogy beyond methods as an alternative to abandon the narrow vision of teaching to reach the particular, practical and possible. In addition, he believes that any methodological strategy is relevant only when it is sensitive to a specific group that follows individual goals in a particular institution, framed in a social context.

When comparing definitions of quality of education, it can be glimpsed that we cannot fall into tangible measures of knowledge by reducing it to a concept. As stated by Freire (1972) the analysis of scientific concepts is a necessary condition for a reflective practice. Interrogating and making them controversial is a way of exercising and promoting critical thinking and emancipatory actions. Among the diverse conceptual approaches, Rodriguez Arocho's (2010) can be highlighted, as he reflects on the concept of educational quality from the historical-cultural perspective, analyzes the unreflective way in which discourses about quality in business contexts have been transferred to educational management, unveiling an origin based on the neoliberal model and driven by the processes that characterize globalization. Arizmendi (1993), on the other hand, affirms that education is an essentially human act; the student goes to school not only to obtain and accumulate knowledge and the teacher has a guiding role. UNESCO (2011) presents it as the capacity to solve problems and to continue learning.

In the Colombian context, Velez (2003) proposes a policy on performance evaluation, within the framework of Law 715 of 2001, which provides for the annual evaluation of teachers and school managers, in order to characterize their performance and foster personal and professional development. She states that we Colombians are committed to improving the quality of education and generating strategies to make it possible. One such strategy is "Evaluate for Improving." We can only improve and achieve better quality, if we know where we are and how we are in relation to clear objectives and goals" (Velez, 2003).

Every evaluation around the concept of quality of education reflects different positions taken from different perspectives. Therefore, it is crucial to have the ability to critically discern the best way to foster an educational quality that takes local reality as a starting point.

\section{Method}

\subsection{Participants and Context}

This analysis was carried out with the participation of pre-service English teachers to know their perceptions about the curriculum that underlies their teacher trainig program and to characterize their contributions against a new curriculum design. The study was motivated by some changes currently brewing in the program due to new policies issued by the National Ministry of Education to improve the quality of teacher training programs. The 
BA in English, a ten-semester program, is in the context of a State university and operates with limited resources, but is still governed by the same national regulations. The participating population was made up of 24 eighth-semester pre-service teachers. The were selected because they had already completed more than $80 \%$ of their courseload and therefore had full knowledge of the curriculum and educational process of the program.

\subsection{Design and Instruments}

In order to know about the pre-service teachers' voices concerning the reforms, a descriptive analysis was carried out through a Likert scale questionnaire with open and closed-ended questions (see Appendix I). Closed-ended questions allowed us to know about their perceptions with respect to the relevance that they give to the three educational components (disciplinary, professional and humanistic) of the curriculum for their wholistic education. The open-ended questions were intended to provide broader explanation of the reasons for the score given to the closed-ended questions, while motivating pre-service teachers to have a proactive attitude and to feel included in the curriculum design of the program.

\section{Results}

The assessment of pre-service teachers' perceptions in a context where there are guidelines often disconnected from the social and cultural context is an opportunity for curriculum committees to make informed and reality-based decisions. Similarly, this allows for a curriculum design that is more in line with the needs and expectations of future teachers, who early in their teaching lives learn important lessons about student-centered learning, which will nurture their spirit as facilitating, reflective and critical teachers.

In the questionnaire administered to the 24 participants, it can be perceived that, although in the oral discourse they seem to be aware of the need to receive a wholistic education, the degree of importance they give to the subjects they have to enroll decreases as the level of interdisciplinarity increases. That is, the majority of participants gives more relevance to disciplinary subjects and less to humanistic ones. They were asked to score from 1 to 3 each subject in the curriculum with the following equivalences: $1=$ Very relevant, $2=$ Relevant and 3 $=$ Not relevant. Figure 1 presents the consolidation of the answers given to the degree of relevance of the disciplinary component, which has a total of 16 subjects. $80.99 \%$ of particpants marked this group of subjects as very relevant, while only $3.13 \%$ found no relevance in some of the subjects of this component.

\section{Disciplinary}

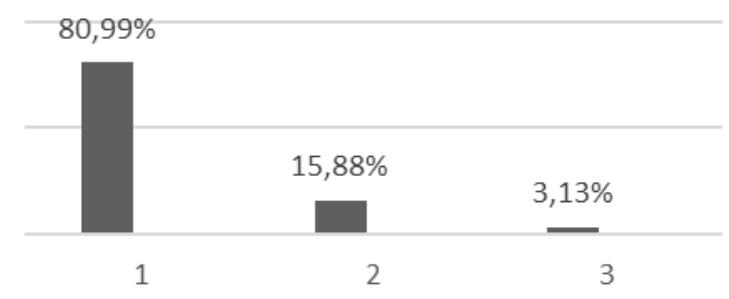

Figure 1. Disciplinary component

The professional component is in the middle of the three and has 15 subjects. $56.11 \%$ of participans scored them as relevant. In these subjects, they find application to disciplinary knowledge and relate it with the teaching practicum, although their appreciation is not the same for all subjects.

\section{Professional}

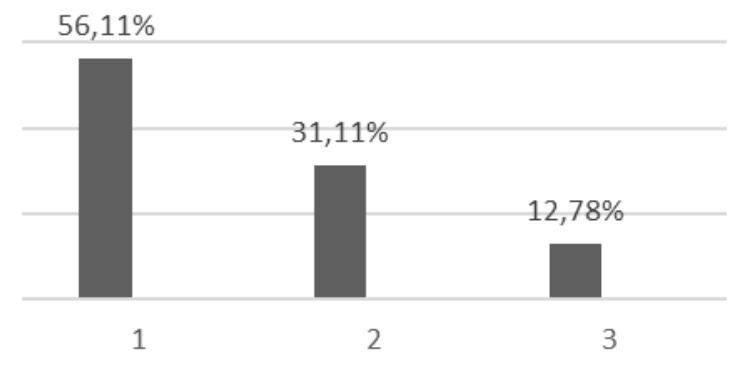

Figure 2. Professional component 
The humanistic component, which has 12 subjects, is the least relevant for pre-service teachers with $36.81 \%$ of negative answers because it is difficult for them to relate some of these subjects to their teacher training.

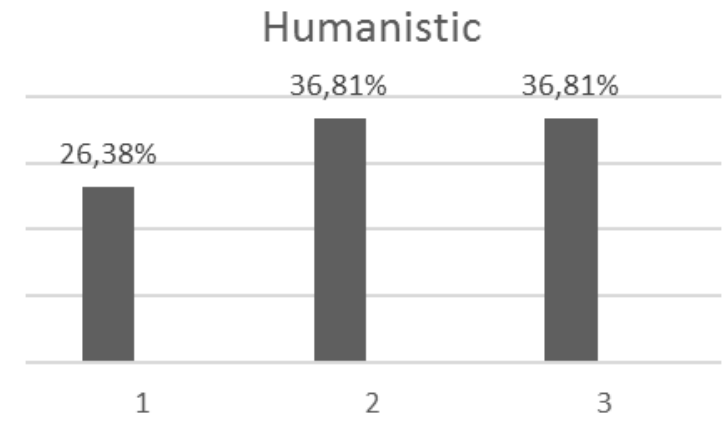

Figure 3. Humanistic component

Additionally, pre-service teachers answered five open-ended questions to provide more information about their perceptions and to propose changes and additions to the curriculum.

Question \# 1. What reasons motivated you to rate some subjects as very relevant?

Among the main reasons they gave are the following: The subject is useful for my professional life, it is representative of all subjects, allows me to grow as a future teacher, I learned relevant aspects of my culture and foreign cultures, I learned new things, I managed to understand how languages are learned, it gives me tools for my career, it is contextualized, classes are meaningful, I can learn new strategies to teach, its content is relevant, the teacher makes it meaningful, it expands students' knowledge and perspectives. In some cases, the content of the subjects is relevant to pre-service teachers, but in the majority of cases, the role of the teacher is so significant that it gets students to involve in the subject.

Question \# 2. What reasons motivated you to rate some subjects as not relevant?

Participants' responses to this question lead to the belief that course content, teacher's lack of commitment and motivation or non meaningful approaches are the main factors to decrease their interest, as exposed in what follows: It is not relevant, it is boring, I had a bad experience, the teacher did not have good teaching strategies, the teacher gave it a bad approach, it is not related to my field, there is no relation between theory and practice, it does not contribute to my professional development.

Question \# 3. Do you consider that the curriculum meets students' needs? How?

Answers include these Yes, because I think it has the necessary elements for our education; for the most part it contributes to me as a person and professional; some subjects only serve administrative interests; yes, they provide guidance and strategies for success as English teachers; yes, because the curriculum provides a variety of subjects that help develop English skills; Sometimes; starting the practicum in eighth is not good, it should start before; Yes, we have excellent teachers who help us learn the language and give us the tools to teach it; Most of the curriculum is designed based on our needs; Yes, the curriculum includes learning styles; Yes, each subject contributes to the professional development of the future teacher.

Question \# 4. What changes do you propose to make in the curriculum? What subjects would you add? I would change the focus of some, add more didactics, practices and research, include a subject of special needs, avoid irrelevant subjects, teaching English in rural contexts, class management, content through English, teaching English to children, include other languages, start the practicum earlier. Particular interests emerge and give light to the possibilities of reaching consensus to generate changes that benefit an academic community.

Question \# 5. What do you think of the new policies of the National Ministry of Education that propose to increase the number of hours of practicum starting these in earlier semesters? The majority of participants answered this question affirmatively for reasons like the following: It will help us become familiar with the school, the three semesters we have now are not enough, we get more involved in teaching, students will test their skills earlier, we will know the context better, we will learn to put theory into practice, we will know reality before.

A relevant issue to highlight of pre-service teachers' responses is that not only do their perceptions change when 
they are included in curriculum decisions, but they also help change teachers' perspectives. In a previous meeting with the curriculum committee, teachers found the change in pedagogical practices as being an inappropriate and difficult-to-implement task. In addition, we had believed that pre-service teachers would be overwhelmed and unmotivated with so many semesters of practicum; however, their answers presented us with a different picture and new alternatives for curriculum design.

\section{Conclusions}

The different constructs studied present a controversial panorama about what should be taken into account to bridge the gap between curriculum planning policies and pre-service teachers' needs. A curriculum that satisfies interests outside the university cannot be meaningful to the beneficiaries; on the contrary, it will generate tensions at school level. It is essential to take into account the discussion generated about the localization of learning, as Canagarajah (2005) states, "situated and socially negotiated knowledge." That is to say, we need to recognize the local context, as we approach the globality so necessary to open our horizons to the universal reality that frames us.

Moreover, it is necessary to see education beyond the cost-benefit ratio, to humanize knowledge. The standards we are measured against create tensions in pre-service teachers, in-service teachers and managers, and sometimes become the only reason for planning and instruction. Dewey's assertion makes sense, because it is necessary to enjoy the road as much as the arrival. When the pre-service teachers surveyed perceived the subjects as useful and meaningful to their personal and professional life, they rated them as relevant. A pedagogy at the level of the student. Students learn in activities where reality is present. It is not enough to prepare them for life, but to see school as life itself, with meaning during its realization (Dewey, 1933).

We are in need for more reflective teachers to guide and facilitate the learning process, while empowering their students with tools that allow them to appropriate knowledge, so that they can make a critical reading of their reality. This empowerment will enable them to believe in themselves and develop skills to solve everydayproblems and improve their environment, which should ultimately be the reason for learning.

\section{References}

Arizmendi, R. (1993). Situación actual de la universidad Mexicana. Revista de la Educación Superior, 22(1), $1-6$.

Canagarajah, S. (2005). Reconstructing local knowledge, reconfiguring language studies. In S. Canagarajah (Ed.) Reclaiming the local in language policy and practice (pp. 3-24). Mahwah, NJ: Erlbaum.

Dewey, J. (1933). How we think: A restatement of the relation of reflective thinking to the educative process. Lexington, MA: Heath.

Krawczyk, N. (2002). La reforma educativa en América Latina desde la perspectiva de los organismos multilaterales. Revista Mexicana de Investigación Educativa, 7(16), 627-663.

Freire, P. (1972). Pedagogía del oprimido. Buenos Aires: Tierra Nueva y Siglo XXI Editores.

Freire, P. (1989). La educación como práctica de la libertad. (19th Ed.). Rio de Janeiro: Paz e Terra.

Haralambos, M. (1991). Sociología: Temas y Perspectivas. Madrid: Morata.

Imen, P. (2008). Políticas Educativas y modos de trabajo docente en Argentina: un recorrido por las imposiciones y resistencias entre la reproducción y la emancipación. Perspectiva, 26(2), 401-432. https://doi.org/10.5007/2175-795x.2008v26n2p401

Kumaravadivelu, B. (2001). Towards a postmethods pedagogy. TESOL Quarterly, 35(4), 537-560. https://doi.org/10.2307/3588427

Martinic, S., \& Pardo, M. (2000). Economía política de las reformas educativas en América Latina. Opreal, Memorias de Congreso.

Meighan, R., \& Siraj-Blatchford, I. (1997). A sociology of Educating (3rd Ed.). United Kingdom: Cassell.

Ministerio de Educación Nacional. (1992). Ley 30 de 1992.

Ministerio de Educación Nacional. (2016). Resolución Nº 2041 de 3 de febrero de 2016

Rivero, J. (2000). Reforma y desigualdad educativa en américa latina. Revista Ibero-Americana de Educación, 23, 103-133.

Rodriguez Arocho, W. (2010). El concepto de calidad educativa: una mirada crítica desde el enfoque históricocultural. Actualidades Investigativas en Educación, 10(1), 1-28. 
Rojas-Oviedo, I. (2013). Lecciones para docentes: Sobre currículo, gestión escolar e investigación. Bogotá: Redipe.

Taborda, J., \& Buriticá, O. (2007). El cientifismo como enfoque curricular contemporáneo. Revista Latinoamericana de Estudios Educativos, 3(1), 103-122.

Tomlinson, B. (2003). Developing materials for language teaching. London: Continuum.

Tyler, R. (1949). Basic principles of curriculum and instruction. Chicago: University of Chicago Press.

Torres, J. (1998). El currículo oculto (6th Ed.). Madrid: Morata.

UNESCO. (2011). La UNESCO y la educación. Francia: UNESCO

Velez, C. (2003). Manual de la evaluación de desempeño. Bogotá: Ministerio de Educación Nacional.

Zaccagnini, M. (2004). Reformas educativas: espejismos de innovación. Revista Iberoamericana de educación. Retrieved from http://www.infoamerica.org/teoria_articulos/lorenzano01.pdf

\section{Appendix A}

\section{Questionnaire}

Dear student,

The objective of this questionnaire is to know your perception about the curriculum of the Bachelor in English Program.

1) Please grade each subject (you will find the curriculum attached) depending on the level of relevance for your professional education, as follows: $1=$ Very relevant $2=$ Relevant $3=$ Not relevant

2) What reasons motivated you to rate some subjects as very relevant?

3) What reasons motivated you to rate some subjects as not relevant?

4) Do you consider that the curriculum meets students' needs? How?

5) What changes do you propose to make in the curriculum? What subjects would you add?

6) What do you think of the new policies of the National Ministry of Education that propose to increase the number of hours of practicum starting these in earlier semesters?

\section{Copyrights}

Copyright for this article is retained by the author(s), with first publication rights granted to the journal.

This is an open-access article distributed under the terms and conditions of the Creative Commons Attribution license (http://creativecommons.org/licenses/by/4.0/). 